\title{
ASSESSING THE EFFECTS OF SPATIAL INTERPOLATION OF RAINFALL ON THE STREAMFLOW RESPONSE
}

\author{
Sreedevi.S ${ }^{1}$ and Eldho T.I ${ }^{2}$ \\ ${ }^{1}$ Research Scholar, Department of Civil Engineering, Indian Institute of Technology \\ Bombay, Mumbai, 400076, India \\ ${ }^{2}$ Professor, Department of Civil Engineering, Indian Institute of Technology Bombay, \\ Mumbai, 400076, India
}

\begin{abstract}
Precipitation within a river basin varies spatially and temporally and hence, is the most relevant input for hydrologic modelling. Various interpolation methods exist to distribute rainfall spatially within a basin. The sparse distribution of raingauge stations within a river basin and the differences in interpolation methods can potentially impact the streamflow simulated using a hydrologic model. The present study focuses on assessing the effect of spatial interpolation of rainfall using Theissen polygon, Inverse distance weighted $(I D W)$ method and Ordinary Kriging on the streamflow simulated using a physically based spatially distributed model-SHETRAN in Vamanapuram river basin in Southern Kerala, India. The SHETRAN model in the present study utilises rainfall data from the available rain gauge stations within the basin and potential evapo-transpiration calculated using Penman-Monteith method, along with other input parameters like soil and landuse. Four years of rainfall and evapo-transpiration data on a daily scale is used for model calibration and one year data for validation. The performance of the different spatial interpolation methods were assessed based on the Mean Annual flow and statistical parameters like NashSutcliffe Efficiency, coefficient of determination. The ordinary kriging and IDW methods were found to be satisfactory in the spatial interpolation of rainfall.
\end{abstract}

\section{KEYWORDS}

Rainfall-runoff simulation, Hydrologic model, Inverse distance weighted method, Ordinary Kriging, SHETRAN, Streamflow

\section{INTRODUCTION}

Hydrologic models can be used to predict the future performance of a catchment or region of interest. Performing hydrologic modeling at a watershed scale is particularly important for efficient management of water resources within the river basin. Physically based models use parameters with physical significance and have the ability to improve calibrations on the basis of physical reasoning [1]. SHETRAN is a physically based spatially distributed modeling system for runoff estimation, sediment transport and contaminant migration capable of application on a river basin scale [2] [3]. The quality of model simulation is highly dependent on the accuracy of input parameters. Rainfall varies spatially and temporally across a basin. The spatial heterogeneity of rainfall in the model is accounted by using various spatial interpolation methods. The impact of different spatiotemporal resolution of rainfall input on simulated runoff, using hydrological models other than SHETRAN, was examined by many studies [4, 5, 6, 7]. Dirks et al., compared four interpolation methods namely the Inverse distance weighted method, Theissen polygon, Kriging and Areal mean method using rainfall data from a network of thirteen rain gauges in Norfolk Island[8]. Kriging method could not provide any significant improvements over other DOI:10.5121/civej.2016.3216 
methods. For a dense observation network, the authors recommended the application of IDW method. Buytaert et.al [9] compared Theissen polygon(THI) and Kriging methods for the spatial and temporal variability of precipitation in the south Ecuadorian Andes. It was found that spatial interpolation based on the Kriging gives better results than that based on THI. However, the accuracy of both methods was improved due to the account of external trends. Theissen polygon method for daily rainfall data provided better forecast of streamflow from Wetspa model compared to IDW and Universal kriging for the Gharesou Basin, Iran [10].

The literature highlights the need to represent precipitation in a better way as input in hydrologic modelling. In the present study, the performance of different spatial interpolation methods on simulated streamflow from Vamanapuram river in Kerala, India were assessed based on the Mean Annual flow and statistical parameters like Nash-Sutcliffe Efficiency, coefficient of determination. The parameterization of the model for manual calibration has been carried out. SHETRAN model is calibrated and validated using five year daily time series data and the performance of different spatial interpolation methods were compared.

\section{Materials and Methodology}

\subsection{STUDY AREA AND THE DATA USED}

The Vamanapuram river basin with a catchment area of 787 sq. $\mathrm{km}$. is located mainly in Thiruvananthapuram district with a small part falling in Kollam district of Kerala state, India. The basin is bounded by latitudes of $8^{\circ} 35^{\prime} 24^{\prime \prime} \mathrm{N}$ and $8^{\circ} 49^{\prime} 13^{\prime \prime} \mathrm{N}$ and longitudes of $76^{\circ} 44^{\prime} 24^{\prime \prime} \mathrm{E}$ and $77^{\circ} 12$ ' 45' E with Nedumangad Taluk of Thiruvananthapuram district in the South, Kottarakkara Taluk of Kollam districts in the North, Tamil Nadu in the East and Arabian Sea in the West. Figure 1 shows the location of the basin. The basin receives an annual average rainfall of $3200 \mathrm{~mm}$. The area receives rainfall mainly during Southwest (June-September) and Northeast monsoons (October-November).The digital elevation model for the study area was obtained from earth explorer (http://earthexplorer.usgs.gov/). ASTER DEM of 30m resolution was aggregated to $1 \mathrm{~km}$ mesh in Arc Map 10.1, to be used in the SHETRAN Model. Resourcesat-1 AWiFS, of 0.00045 Degree spatial resolution (February 2009) prepared by National Remote Sensing Centre (http://bhuvan.nrsc.gov.in) was downloaded for processing in ArcMap 10.1. The maximum likelihood method using the supervised classification technique was used to prepare the landuse map. The resulting image was aggregated to $1 \mathrm{~km}$ by $1 \mathrm{~km}$ mesh to be used in SHETRAN model. Soil data in the form of soil texture and soil depth map were procured from the Directorate of Soil survey and conservation, Trivandrum. The rainfall data of five raingauge stations installed within the river basin was procured from the Hydrology Project-II, Thiruvananthapuram and National Data Centre, Pune. The discharge data of Vamanapuram river at Ayilam station was obtained from the Water Resources Information system (http://www.india-wris.nrsc.gov.in/wris.html). The gauging station is monitored by Central Water Commission. The Metereological variables for calculating Potential Evapotranspiration using Penman-Monteith equation were collected from National data Centre. The methodology adopted for the present study is shown in Figure 2. The location of raingauge stations are shown in

Figure 3. 
Civil Engineering and Urban Planning: An International Journal (CiVEJ) Vol.3, No.2, June 2016

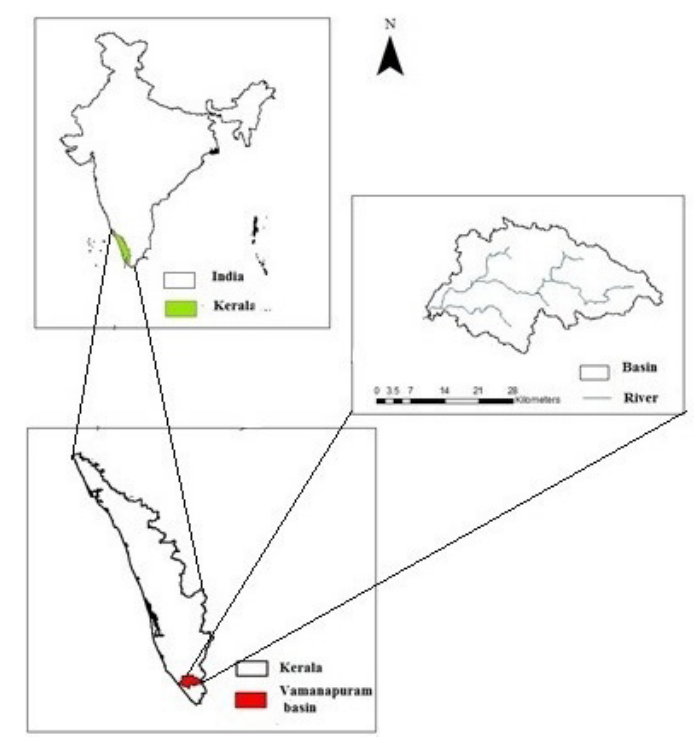

Figure 1 Location of Vamanapuram basin

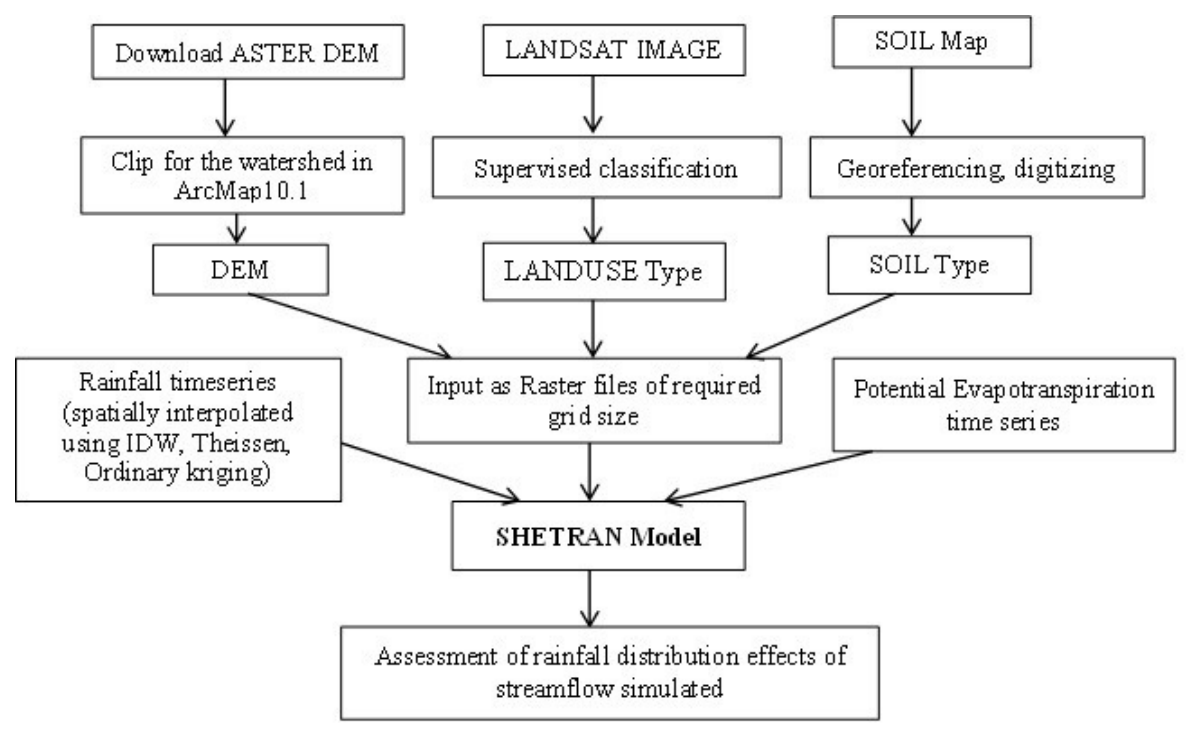

Figure 2 Flowchart showing methodology

\subsection{RAINFALL INTERPOLATION PROCEDURES}

A brief description of the interpolation methods used in this paper is presented here. Theissen polygon and IDW are deterministic methods whereas Ordinary Kriging is a geostatistical method. In the Theissen polygon method, the catchment area is divided into polygons so that each polygon contains a single point of sampling [14]. Each interpolated point (centre of each grid) takes the value of the closest sampled point. Theissen polygons were generated using ArcMap 10.1. The inverse distance weight (IDW) method [15] was employed to spatially distribute the daily rainfall. The rainfall at 5 rain gauge stations were distributed spatially to $5 \mathrm{Km}$ by $5 \mathrm{Km}$ grids for IDW. In Kriging method, the value of the interest variable is estimated for a particular point using a weighted sum of the available point observations. The weights of the data are chosen so that the 
interpolation is unbiased and the variance is minimized. Kriging method takes into account the spatial dependence structure of the data. There are several types of Kriging, which differ according to the form applied to the mean of the interest variable. In Ordinary Kriging, the mean is constant but unknown. For the present study, an unbounded stable variogram model was chosen for Kriging. IDW and Kriging where carried out using MATLAB R2012b.

Figure 4 represents the spatial variation of rainfall by annual means for the period from 2006 to 2010 obtained by using different interpolation methods.

\subsection{OVERVIEW OF SHETRAN MODEL}

SHETRAN (SHE-Transport) model was developed from the SHE system [13], a physically based spatially distributed system for modeling coupled surface and subsurface water flow in river basins. SHETRAN model has many improvements and additions compared to the SHE Model. The three dimensional variably saturated sub-surface water flow model [14] and the sediment and contaminant transport components $[15,2]$ are some of the major additions to the model. The model was developed within the Water Resources Systems Research laboratory, School of Civil engineering and Geosciences, University of Newcastle upon Tyne. Inorder to solve the partial differential equations for flow and transport, SHETRAN uses finite difference method. The catchment area is discretized into rectangular computational elements and the underlying soil zone and aquifer are represented by columns of cells that extend downwards from each of the surface grid squares. River network, represented by links is assumed to run along the boundaries of grid squares. The spatial variability in catchment properties, soil, landuse, topography and metereological inputs are incorporated explicitly into the catchment model by the grid and column structure of the model.

\section{Model Calibration and Validation}

In this study, parameter ranges for calibration of the model were fixed based on literature values. The parameters like Strickler overland flow resistance coefficient, Actual Evapotranspiration/Potential Evapotranspiration ratio and soil parameters namely soil depth, saturated hydraulic conductivity, soil water retention and hydraulic conductivity functions were identified as key parameters required to be specified using field or calibrated data for flow simulations from studies conducted by Parkin [14], Bathurst et al. [5,6] and Birkinshaw et al. [18]. A sensitivity analysis of the above six parameters is performed to arrive at the final values. The data collected was split into two parts- calibration and validation, with calibration being performed for the period from year 2006 to 2009 and validation for the period from January 2010 to December 2010. The model predictive power was assessed based on Nash-Sutcliffe Efficiency [19]. 


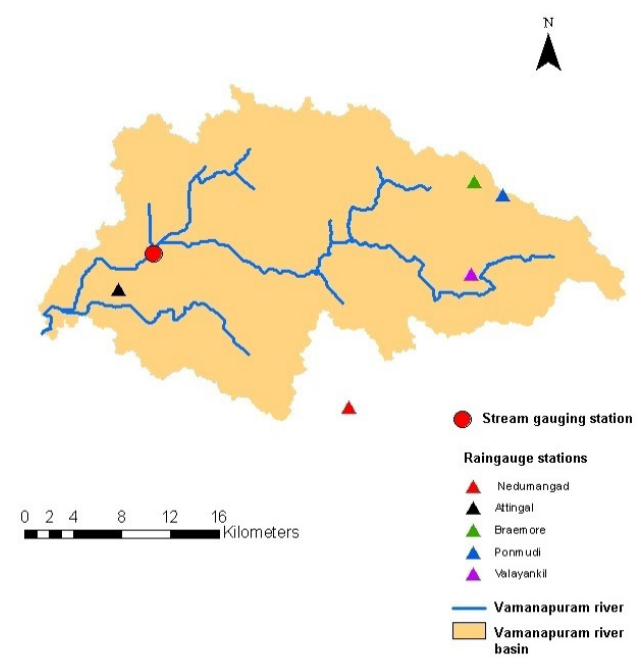

Figure 3 Location of raingauge and streamgauge stations within the Vamanapuram basin

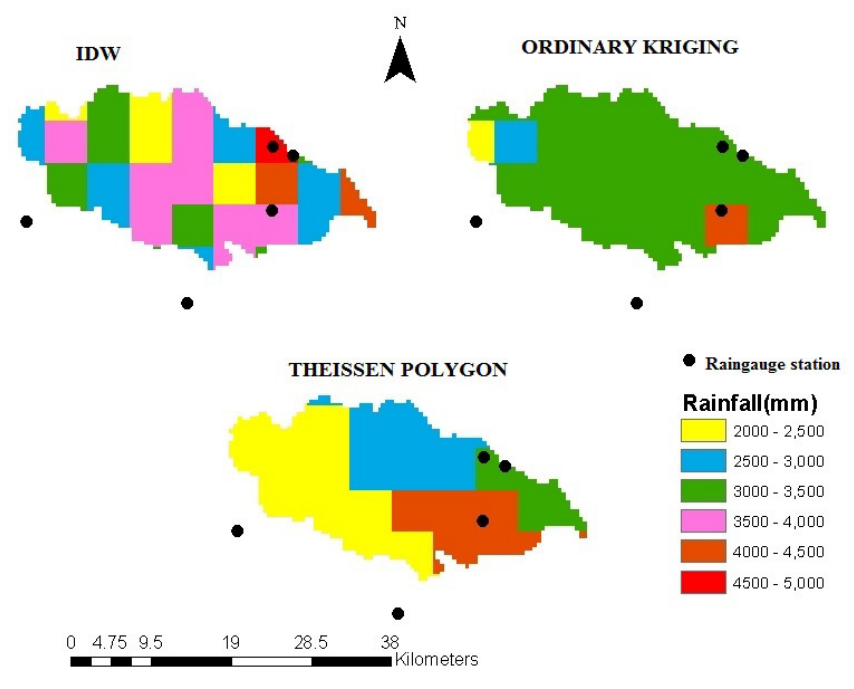

Figure 4 Mean Annual precipitation from 2006 to 2010 using different interpolation methods

\section{RESULTS AND DISCUSSION}

Performance of the different rainfall interpolation methods on streamflow simulated by SHETRAN was assessed based on various statistical parameters like Nash-Sutcliffe Efficiency (NSE), RMSE (Root Mean Square Error), coefficient of determination $\left(\mathrm{R}^{2}\right)$ and also the mean annual flow (Table 1).

Streamflow is converted in units of millimeter by dividing streamflow in cumecs by the watershed area. Mean annual daily flow is obtained by dividing the sum of all the individual daily flows by the number of daily flows recorded for the year. Mean annual flow for the period of record was calculated by taking sum of mean annual flows available for each year of the record, divided by the number of years of record to obtain the long-term mean annual flow for the period of record [20]. Streamflow simulated using Theissen polygon method showed a large difference 
in mean annual daily flow during calibration and validation phase although the statistical parameters showed a satisfactory performance. Inverse distance method showed very less difference in mean annual daily flow from the observed during calibration. Statistical parameters for IDW also indicate the high performance of this method. The mean annual flow simulated using Ordinary Kriging method showed least difference from the observed in comparison to the other two methods. The simulated discharge hydrographs for the calibration and validation phase, obtained by different rainfall interpolation methods employed in the study are presented in Figure 5 and

Figure 6. It can be observed from the Figure 5 that there is significant difference in the simulated streamflow using rainfall from IDW, Theissen and Kriging methods. Streamflow simulated using IDW interpolated rainfall showed good match with the observed streamflow, in comparison to the other methods for the calibration and validation phase.

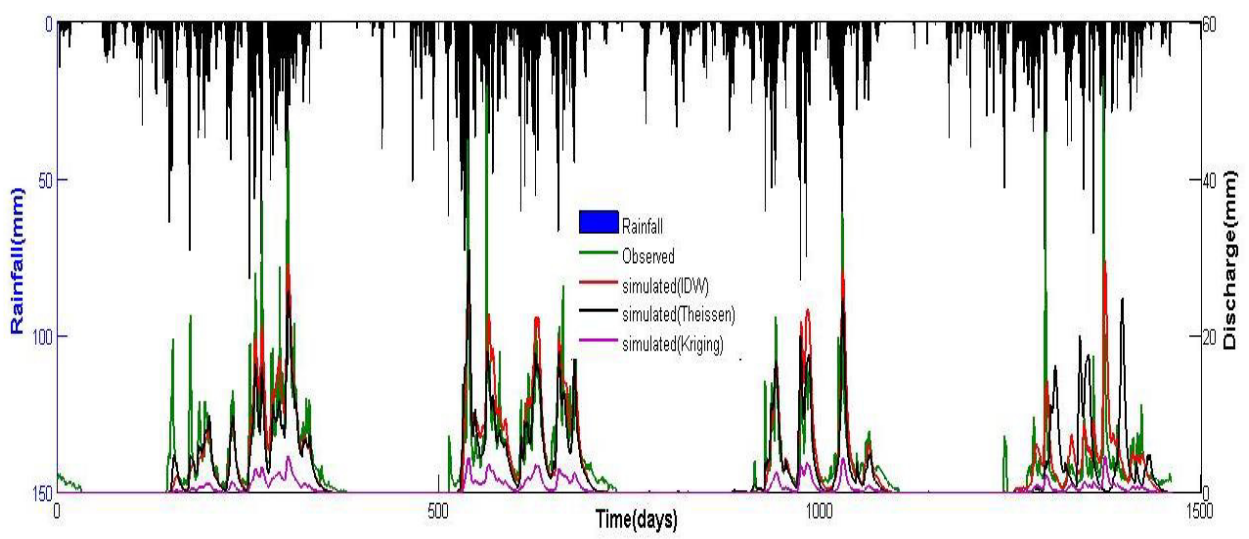

Figure 5 Comparison of discharge simulated using different rainfall spatial interpolation methods for the period 2006 to 2009 (calibration phase)

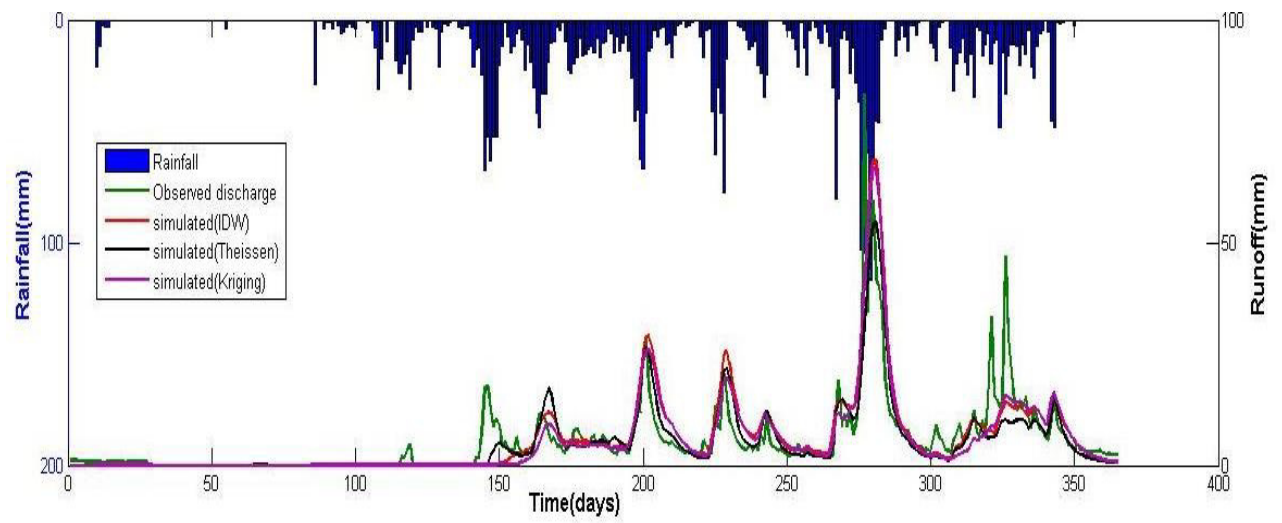

Figure 6 Comparison of discharge simulated using different rainfall spatial interpolation methods for 2010(validation phase) 
Civil Engineering and Urban Planning: An International Journal (CiVEJ) Vol.3, No.2, June 2016

Table 1 Comparison of Model simulation for different interpolation methods

\begin{tabular}{|l|l|l|l|l|l|c|}
\hline Method & Year & NSE & $\mathrm{R}^{2}$ & RMSE & $\begin{array}{l}\text { Mean } \\
\text { Annual } \\
\text { daily } \\
\text { flow(mm) }\end{array}$ & $\begin{array}{l}\text { Difference in } \\
\text { flow (\%) }\end{array}$ \\
\hline IDW & $\begin{array}{l}2006 \text { to } \\
2009\end{array}$ & 0.671 & 0.698 & 3.261 & 3.403 & 0.147 \\
\hline & 2010 & 0.616 & 0.700 & 5.362 & 5.835 & -8.760 \\
\hline $\begin{array}{l}\text { Theissen } \\
\text { polygon }\end{array}$ & $\begin{array}{l}2006 \text { to } \\
2009\end{array}$ & 0.512 & 0.535 & 3.976 & 2.930 & 14.026 \\
\hline & 2010 & 0.681 & 0.691 & 4.886 & 4.898 & 8.705 \\
\hline $\begin{array}{l}\text { Ordinary } \\
\text { Kriging }\end{array}$ & 2006 to & 0.4118 & 0.502 & 4.336 & 3.398 & 0.293 \\
\hline & 2009 & & & & & \\
\hline Observed & 2010 & 0.6562 & 0.711 & 5.078 & 5.379 & -0.261 \\
\hline & 2009 & & & & 3.408 & \\
\hline
\end{tabular}

\section{CONCLUSION}

The present study showed that IDW and Ordinary Kriging method outperformed the Theissen polygon method in terms of the mean annual streamflow simulated using SHETRAN model for the Vamanapuram river basin. The visual comparison of simulated streamflows clearly indicated the capability of IDW method in providing more accurate rainfall estimates. In regions with sparse rain gauge stations, it is very essential to incorporate spatial rainfall interpolation methods which can yield good streamflow simulations form distributed models like SHETRAN.

The Ordinary Kriging method used a stable variogram model for the present study and showed satisfactory performance in terms of streamflow simulation. The capability of other variogram models in Ordinary Kriging for rainfall interpolation needs to be explored further. The present study highlights the need to explore different interpolation techniques for streamflow simulation using hydrologic models especially for regions with sparse raingauge networks.

\section{ACKNOWLEDGEMENT}

The authors thank Dr. Birkinshaw, School of Civil Engineering and Geosciences; Newcastle University, UK for the great assistance in clearing all SHETRAN related queries. The authors are grateful to the various departments, - NDC, Pune, Hydrology division Project-II, Thiruvananthapuram and the Directorate of Soil survey and conservation for providing all necessary data required for the present study.

\section{REFERENCES}

[1] Bathurst JC (1986) Sensitivity analysis of the Systeme Hydrologique Europeen for an upland catchment. J HydrolVol. 87 pp 103-123

[2] Ewen, J.,(1995). Contaminant transport component of the catchment modelling system SHETRAN. In: Trudgill, S.T., (Ed.), Solute Modelling in Catchment Systems, Wiley, Chichester, UK, pp. 417441.

[3] Ewen, J., Parkin, G., O'Connell, P.E., (2000). SHETRAN: distributed river basin flow and transport modeling system. Proc. Am. Soc. Civil Engrs, J. Hydrol. EngngVol. 5, No. 3, 250-258. 
Civil Engineering and Urban Planning: An International Journal (CiVEJ) Vol.3, No.2, June 2016

[4] Faure`s, J.-M., D.C. Goodrich, D.A. Woolhiser, and S. Sorooshian, (1995). Impact of Small-Scale Spatial Rainfall Variability on Runoff Modelling. Journal of Hydrology Vol.173, pp.309-326.

[5] Bathurst JC, Ewen J, Parkin G, O'Connell PE, Cooper JD (2004) Validation of catchment models for predicting land-use and climate change impacts. 3. Blind validation for internal and outlet responses. J HydrolVol.287 pp 74-94

[6] Bathurst JC, Birkinshaw SJ, Cisneros F, Fallas J, Iroumé A, Iturraspe R, Novillo MG, Urciuolo A, AlvaradoA, Coello C, Huber A, Miranda M, Ramirez M, Sarandón R (2011) Forest impact on floods due to extreme rainfall and snowmelt in four Latin American environments 2: model analysis. J Hydrol Vol.400 pp292-304

[7] Maskey, S., V. Guinot, and R.K. Price(2004). Treatment of Precipitation Uncertainty in RainfallRunoff Modelling: A Fuzzy Set Approach. Advances in Water Resources Vol. pp 27:889-898.

[8] K. N. Dirks, J. E. Hay, C. D. Stow, and D. Harris, (1998),High-resolution Studies of Rainfall on Norfolk Island, Part 2: Interpolation of Rainfall Data, J. Hydrol., Vol.208.pp187-193

[9] W. Buytaert, R. Celleri, D. B. Willems, and G. Wyseure(2006) Spatial and Temporal Rainfall Variability in Mountainous Areas: A Case Study from the South Ecuadorian Andes J. Hydrol., Vol.329, pp 413-421

[10] H.Zeinivand,(2015) Comparison of Interpolation Methods for Precipitation Fields Using the Physically Based and Spatially Distributed Model of River Run off on the Example of the Gharesou Basin, Iran Russian Meteorology and Hydrology, Vol. 40(7), pp. 480-488

[11] Tetzlaff, D. and S. Uhlenbrook, (2005)Effects of Spatial Variability of Precipitation for ProcessOriented Hydrological Modelling: Results From Two Nested Catchments. Hydrology and Earth System Sciences Vol. 9 pp.29-41.

[12] Masih, I., Maskey, S., Uhlenbrook, S., and Smakhtin, V.: Assessing the impact of areal precipitation input on streamflow simulations using the SWAT model, J. Am. Water Resour. As., Vol.47, pp.179195,doi:10.1111/j.1752-1688.2010.00502.x, 2011b

[13] Abbott MB, Bathurst JC, Cunge JA, O'Connell PE, Rasmussen J. (1986). An introduction to the European Hydrological System-Syst'emeHydrologiqueEurop'een, 'SHE', 2: structure of a physically-based, distributed modelling system. Journal of Hydrology Vol.87 pp 61-77.

[14] Parkin G. (1996) A three-dimensional variably-saturated subsurface modelling system for river basins. PhD thesis, University of Newcastle upon Tyne, Newcastle upon Tyne, UK.

[15] Wicks JM. (1988). Physically-based mathematical modelling of catchment sediment yield. PhD thesis, University of Newcastle upon Tyne, Newcastle upon Tyne, UK.

[16] Chow VT (1959) Open-channel hydraulics. International Student Edition, McGraw-Hill

[17] Donald Shepard (1969) A two-dimensional interpolation function for irregularly spaced data, ACM '68: Proceedings of the 1968 23rd ACM National Conference, ACM, pp 517-524

[18] Birkinshaw SJ, Bathurst JC, Iroumé A, Palacios H (2011) The effect of forest cover on peak flow and sediment discharge - an integrated field and modelling study in central-southern Chile. Hydrol Process Vol.25, No.8, pp1284-1297.

[19] Nash JE, Sutcliffe JV (1970) River flow forecasting through conceptual models part I - a discussion ofprinciples. J HydrolVol 10, pp282-290

[20] http://streamflow.engr.oregonstate.edu/analysis/annual/

\section{Authors}

1. Sreedevi.S, Research Scholar in Department of civil engineering, Indian Institute of technology Bombay

2. Prof. T. I Eldho is a Chair professor in Water Resources Engineering, Department of civil engineering, Indian Institute of technology Bombay. He works in the area of watershed management, groundwater, climate change, computational fluid dynamics and application of simulation-optimisation methods in water resources and environmental engineering. 